\title{
All aboard the U.S.S. New Zealand? Voyaging through the literary responses to the American 'occupation,' 1942-1944
}

\author{
Daniel McKay \\ University of Pretoria, Pretoria, South Africa \\ e-mail: dem52@uclive.ac.nz
}

\begin{abstract}
This article reviews and compares the literary fictions of the United States and New Zealand, as they have sought to respond to the 'occupation,' 1942-1944. During the period in question, approximately 100,000 United States Army and Marine Corps servicemen landed and resided in New Zealand, where they undertook final preparations for the island campaigns of the Pacific War. In the aftermath of the war, American fiction writers wrote of the social and cultural difficulties endured by New Zealand civilians, but New Zealand writers took longer to come to terms with the events.
\end{abstract}

Keywords Pacific War · New Zealand · Māori · Womanising · Fistfights · James A. Michener · Leon Uris · Pat Booth · Nicholas Edlin

We had felt, for the Americans of that first invasion, simply dislike - a feeling that ranged from mild to bitter according to the individual case. We had disliked them because they were foreign, because they had strange accents and chewed gum, because they flashed money about and lavished what it could buy on our women, while the best of our men were fighting and dying in the deserts of North Africa. We had disliked them because they had left their used condoms about in our parks, stamped in blue ink 'U.S. Armed Forces. To be used for disease prevention only' - as if our girls, and not their soldiers, carried the diseases; and as if the children they left behind them were a part of their foreign aid programme and intended to improve our bloodstock.

C. K. Stead, Smith's Dream 
Now, the remarkable period when the American servicemen were in New Zealand. A great time for us. Great excitement. The big ships coming in with the New Zealand band on shore playing Deep in the Heart of Texas. Then race-courses, motor-camps, schools moved into; boats requisitioned; huge woolsheds taken over, hospitals built in no time at all. Money everywhere. We gained. No mistake about it. A hundred thousand affluent men came into the country. I would say, at any one time, thirty thousand here. Another city dropped into a few areas of the North Island, having a total population of a few hundred thousand.

\section{Yolanda Drummond, Meeting the Americans}

The preceding epigraphs are fiction and, contrary to what their opinionated language might lead one to assume, one finds them sandwiched within novels that do not aspire to any resounding commentary on American habits in wartime New Zealand, much less in occupation scenarios generally. Though by no means flippant, they are passing comments only, and not intended didactically. The American reader therefore need not take umbrage at or comfort in their throwaway value judgements, and yet, as far as I can tell, the passages' polarity provides as neat a bisection as one is likely to find at other times and places, or in other forms and media. There is, in short, something universal about them, in essence if not in particulars. When New Zealanders recall the American occupation of their country, which followed on Pearl Harbor and tailed off as United States Marines and Infantrymen began to roll back Japanese imperial forces, they do so with mixed feelings that, while serving to countermand any 'extremist' positions, nonetheless coalesce around in-group/out-group affiliations. In this they are not unique. No matter the military or historical backdrop, an occupied territory or country always involves civilians who stare at one another, if they deign to do so at all, as though a chasm had opened up between them (which it surely has, though the occupying forces would berate themselves too harshly to believe that such divisions were solely of their own making). Provided that one sifts through enough records or talks to enough people, one quickly sees that this is a rule which admits no exception, and the best writers and artists can get considerable mileage out of our mistaken assumptions on that score. In M. K. Joseph's novel, A Soldier's Tale (1976), for example, a lascivious British Sergeant takes up residence with a former mistress to German military officers and learns that the Nazi occupation of France was not without its proponents in that country. As a former serviceman of World War II, Joseph was sympathetic to those 'fallen women' who underwent accusations of 'collaboration horizontale' but he does not portray Belle as an oblivious victim either. In order to survive her circumstances, Joseph clearly discerned that Belle would have to know more than she let on, as indeed do all civilians who make it their business to take up a position in respect to (or 'under') their occupiers. Reviewing her defence, the reader struggles beneath the weight of recognising Belle's moral incarceration alongside her timelessness. By and large, her 'guilt' is taken for granted by both characters and reader, but so too is the spectral familiarity of a woman who accepts the inevitability of a bodily invasion following a military defeat. The tension that emerges from weighing Belle's rhetorical 'position' against 
how she is 'positioned' in accordance with group directives ('tribal' directives may not be too wide of the mark) alerts us to the value of Joseph's novel as a milestone in New Zealand literature.

Still, it is one thing to write about what happens to the women of a conquered country on the other side of the world, and quite another to take stock of how the women of one's own country behaved at roughly the same time. As we shall see, those Allied countries that received large numbers of American military personnel during the war years found it possible, and most often preferable, to avoid this discomforting question in the subsequent decades, but over the longer term creative writers would become steadily less averse to answering it. Again, there is nothing particularly uncommon to this trend, and so one must address why New Zealand and not, say, Canadian literature should concern us particularly. To some extent, the literary productions of Allied nations generally function as case studies of shared social phenomena, but one does find disparities in the degree to which each national culture, as well as that of the United States, pays heed to the significance of the respective 'occupations.' 1 As a case study, then, New Zealand's value comes across in the comparisons one can draw between the fiction writings of Americans in the early 1950s and those New Zealanders who turned toward the topic in the latter decades of the twentieth-century and today. Such an analysis would not be possible of every national culture that received American forces in World War II, for not every country came to or sustained the attention of American writers. On that score, one is hard-pressed to speculate why New Zealand, and not other countries, should have warranted the attention that it did (American personnel did not reside there as long as they did in the United Kingdom, nor in such numbers as Australia hosted) but one can begin by imagining the immense relief of the American G.I. who, somehow surviving the brutal island battles of the Pacific, found himself shipped south to a land that, as radioman Leon Uris was later to write, "you almost called home" (1953, p. 388). Part of my purpose in this article is to survey the literature that emerged from this fusion of national cultures, taking the measure of what is contained within the word 'almost,' but I shall also indicate the time taken, and the difficulties addressed, by those New Zealand writers who sought to follow up on the themes and issues staked out in American writing. That the latter paved the way should come as no surprise to anyone familiar with the literary history of the postwar years. Novelists such as Norman Mailer, Herman Wouk, James Jones, and Anton Myrer made their reputations by investing the Pacific War as essentially an American-Japanese affair. The majority of New Zealanders knew otherwise, but finding the words to deliver their ruminations was an elusive undertaking that many, if not most, deferred to an indefinite future occasion, and so the tale of their South Pacific fell into the lap of bestselling authors James A. Michener and Leon Uris.

\footnotetext{
1 In this article, I use the term 'occupation' in the loosest possible sense throughout. The New Zealand 'occupation' (jovially termed an 'invasion' in some writings) was sanctioned by the government and did not in any way compromise the sovereignty of the nation. It followed on the military exigencies of both countries and is thus of an altogether different character to the (capitalised and non-parenthesised) Occupation of Japan. Implied in the term, as I use it, is a conflict between two sets of social mores, the details of which are what I seek to explicate using literary fictions as my source material.
} 
To be fair, these two veterans were acquainted with New Zealand's wartime plight by virtue of their military service, and their depictions of civilian hardships are unstintingly sympathetic. But they approached New Zealand with the appetite of visitors who could consume their topic and then depart for foreign climes, much as the hundred thousand-odd troops originally stationed in the country between 1942 and 1944 were there and gone in the blink of a lovelorn eye. The 'consumed,' for their part, did not deny American writers their right to an opinion, though it is probable that a good many New Zealanders looked with regret, if not consternation, on their place within an American, not British, narrative of the war, much as their prewar selves had grudgingly agreed to integrate Auckland into a Pan American Airways system of Pacific communications over and above British objections (Orders 2003, pp. 17-18). Following this train of thought, perhaps the dearth of New Zealand writings on the occupation was a sign of disgruntlement at the decline of the British Empire and the investiture of the ANZUS Treaty of 1951. But I am more of the opinion that the occupation itself retained a hold on New Zealanders, particularly those residing in Auckland and Wellington, by virtue of the challenges and enticements contained within the topic. After all, at one time a new social world had come dancing on their doorsteps and it is fair to say that, throughout the rest of the twentieth-century, there was nothing in New Zealand that quite equalled it. In this article, we shall voyage through literary writings on either side of the Pacific to observe how, or whether at all, writers sought to convey the socio-cultural changes wrought by the upheaval.

A good number of the shocks wrought by the occupation had their equivalents in Britain and Australia, and anecdotal encounters frequent the reminiscences of many a writer who grew up in the war years. One such, Christopher Hitchens, recalls the American occupation of Britain as an inauspicious or otherwise curious prelude to his later metamorphosis into a New Yorker: "Like many poor relations, we consoled ourselves Englishly with the thought that we made up in good taste and refinement for what we increasingly lacked in money and influence. Americanism in all its forms seemed to be trashy and wasteful and crude, even brutal" (2010, p. 206). Similar sentiments abounded in New Zealand, though among the financial stimuli there were definite windfalls. Nobody, for example, could call seven thousand American tractors 'wasteful,' for without them New Zealand's farmers would not have been able to supply sufficient foodstuffs to American personnel, thereby offsetting Lend Lease to the tune of $£ 81,000,000$ (Lissington 1972, p. 72). Urban businesses likewise flourished, but American commercial practices disturbed long-standing New Zealand traditions, such as the Sunday close-down, and introduced previously unknown customs, such as tipping (Phillips and Ellis 1992, p. 47). New Zealanders were not used to such lavishness, nor could they comfortably accommodate the preferential treatment meted out to free-spending 'Yanks' by restaurateurs, taxi drivers, and hoteliers. Fistfights erupted on more than one occasion, hushed up by media censorship but kept alive in pub room yarns that found their way into published 'fictional' accounts. The most famous among such incidents, Wellington's 'Battle of Manners Street,' involved a series of brawls between U.S. Marines and sailors on one side, and New Zealand merchant seamen and servicemen on the other, possibly exacerbated by another source of social tension: race relations. 
Civilians in Britain and the Dominions looked with curiosity on the segregation of African Americans, but whereas New Zealand had the tāngata whenua, or native Māori peoples, Britain did not. Needless to say, the experiences and treatment of African Americans and Māori were distinct across a range of indices, but both groups found that, to the intrepid and the able-bodied, wartime labour shortages in industrial and urban professions offered fresh opportunities. On coastal areas of the United States, African Americans secured positions as dockyard workers, a grim experience recalled in Chester Himes' novel If He Hollers Let Him Go (1945), which makes clear the chagrin and forbearance shouldered by African Americans on a daily basis. Segregation was unheard of in New Zealand, however, and when some of the American troops attempted to introduce it, they found both Māori and Pākehā, or white peoples, violently uncooperative. So recurrent did clashes between American servicemen and Māori in fact become that the Officer Commanding American Forces, Manurewa, complained to Princess Te Puea at the Turangawaewae Marae that twenty-seven of his men were in hospital following alleged assaults (Bioletti 1989, p. 151). Elevating brutal episodes such as these to the world of literature was to highlight how embarrassingly unallied the Allied Forces sometimes were, and yet there was something gleeful in Michener's depiction of American segregationists getting their comeuppance:

Instinctively, like an infuriated animal, Bill shot out his right fist and knocked the offending Maori [sic] down. "Don't knock into white girls, you damned nigger!" he cried.

When she got back to Christchurch Anne could not explain exactly what had happened next. "All I recall is that suddenly thirty or forty New Zealanders...Barbara, I was never so proud of New Zealanders in my life. One of them shouted, 'You'll not call our Maoris niggers!' There was a terrible fight" (1951, p. 229).

In his short story, "Until They Sail" (1951), Michener would have us believe that cultural differences between New Zealand and the United States arose at Manners Street and elsewhere as a manifestation of New Zealand egalitarianism, which was definitely true, up to a point, and yet the neatness of his binary representation also serves a more obscurantist agenda. For one thing, it accords white New Zealanders the authority to put the hubristic Americans 'in their place' without recourse to Māori forms of social management (Princess Te Puea's bludgeoning warriors are nowhere in evidence). White New Zealanders, that is, retain their privilege as interlocutors, implicitly corresponding to white Americans even as they reprove them. To readers in the United States, there was nothing alarming here. Rather than challenging American social paradigms with the visage of a resistant minority subject, New Zealand comprises an idealised model of paternalism, in which Māori need never intercede on their own behalf. Race relations in the United States might have turned out similarly, were it not for the Civil War and the migratory Negroes. But at least in New Zealand one could drink in the utopian vision of a society in which minorities remained compliant. Moreover, in Michener's world New Zealand appeared to have no serious problems with womanising, arguably the greatest cause of social fracture to follow on the coattails of American servicemen. 
Michener left out little from his story, but when it came to gender relations he underestimated the extent of the social commotion. To be sure, almost every Allied Anglophone nation experienced its share of trysts and romantic liaisons once the 'Yanks' arrived, but New Zealand's situation was pronounced in that respect. Following the outbreak of hostilities in Europe, the 2nd New Zealand Expeditionary Force had departed for service in the British Army, and 3rd Division was later formed for service in the Pacific. These commitments so reduced the number of unmarried New Zealand men at home that when members of the U.S. Army's 37th Division first stepped off their transport ship at Auckland on 13th June they encountered a virtual spinster society. As Michener admitted, "There was a special agony in New Zealand at this time because of the fact that her defenselessness had been caused by her own gallantry" (pp. 222-223). Still and all, for many women there was no immediate agony in the American presence, and the short duration of the servicemen's stay in New Zealand led to all sorts of responses from those who enjoyed their company the most. One group, all of them sensibly-minded ladies, knew full well that it was best not to hope for much, and thus not to commit too much. But then there were the others, plenty of them, and not all of them floozies, who threw caution to the wind (Parr 2010, pp. 218-220). Sensibly or otherwise, by the end of the war 1,396 New Zealand women had married Americans and would depart for the United States as war brides (United States troops in New Zealand 2000 , p. 552). They were the lucky ones, for not every woman who sought official recognition of her romantic relationship found her lover willing to assist in the process. Michener would touch on the emotional scarring wrought by sexual predators on New Zealand women, but chose not to delve too deeply. His task, as he saw it, was to cover up the memory of injudicious encounters, not reopen old wounds. Leon Uris took much the same view in his novel, Battle Cry (1953), though one does find scattered moments of cynicism. In particular, there is the outrageous scene of Andy, a U.S. Marine who romances a married New Zealand canteen lady:

"Andy?"

"Yes?"

"You don't mind if I'm fickle, woman's prerogative. Flickers and dancing do sound nice and I haven't been out in an awfully long time. Could I take you up on it?"

(I've heard everything now, sister. Pining away for your old man in the Middle East? I'll bet you haven't been out since last night). "You bet you can take me up on it. Just lead the way, wherever you want to go. I get liberty Thursday. I'll be ashore around six, how's that?"

"I'll have to get someone to take my shift, but I'll arrange it." (I'm sure you will...old Andy likes married broads, well broken in).

"Where shall I pick you up?"

"Salvation Army Hotel for Women. On Nelson Square, a bit above Lambdon Quay." (Salvation Army Hotel...oh well, I can always get a hotel room).

"See you Thursday and thanks, Pat." (Yeah, see you in the sack, old bean) (p. 270). 
Had Uris sensed the inexorable 'thrust' of this encounter as surely as Andy does, his novel would have taken a remarkably expository turn for its time and provided a much-needed reappraisal of how American troops shape public opinion abroad, much as Eugene Burdick and William Lederer would deliver a critique of the United States' foreign service in The Ugly American (1958). But Uris was a writer who preferred to imagine a world in which individuals are either tempted by indulgences largely exterior to their own psychology or, if their ways are manifestly hedonistic à la Andy, quickly turn over a new leaf with the help of a benign mentor or the admonitions of larger society (in Andy's case, Pat performs the mentor's role and Andy finds himself 'New Zealandised,' cutting timber on her father's farm). These sentimental anachronisms, harking back to a pre-Freudian era, were as misleading in respect to gender relations as Michener was when it came to race. ${ }^{2}$ All through the second half of 1945, New Zealand newspapers had told very different stories of women who had been abandoned, sometimes following pregnancy, or of women who discovered that the man they hitherto believed to be single had another family back in the United States. ${ }^{3}$ To be sure, there were stories of requited love also, but these received less attention in the media and most urban households on the North Island had at least heard tell of 'scandalous' blemishes on the reputation of a neighbourhood girl, her American lover, or both. ${ }^{4}$

In acknowledging the length of time that elapsed before literary writing in New Zealand began to manifest interest in wartime gender relations, one must take into account the ways in which true-to-life or otherwise exaggerated scuttlebutt had already circulated during the war years and shortly thereafter. 'Troubled' international romances did not represent untapped narrative resources. On the contrary, the emergent tales enjoyed an extended life that entered the fabric of New Zealand society, and particularly those Kiwi householders who could perceive a confluence within recent family history. Newspapers in 1945 were filled with allusions and references that required no explaining, though they seldom addressed specific people except in 'agony aunt' columns. The commentary was not snide or snobbish, but, as literary scholar Lydia Wevers makes clear in her analysis of print media, there were "various levels of anxiety produced by the war and New Zealand's part in it, its effect on domestic life, particularly morals, and the alarming

\footnotetext{
${ }^{2}$ Even the most sympathetic reader of Battle Cry will readily admit that Uris' sentimentality dulls the narrative in nauseating ways. As Jonathan Lighter has observed, "It is a world of romance, and in a world of romance everything and everyone conforms to type. Any depth or subtlety one might have hoped for in a novel of 175,000 words is thus forestalled by endless theatrical and familiar incidents and innumerable dialogues of limited originality or interest" (Lighter 2011, para 6).

3 As just one example among many, the following letter was printed by an irate mother living in Wanganui: "I was very pleased to read in 'Truth' that someone has at last raised the question as to what is to become of those New Zealand girls who have been deserted by their American husbands. My daughter married an American Marine about two years ago, and has a son one year old. Since her husband's discharge from the Marines in September, 1944, she has not received one word from him, neither has she received any maintenance for herself and child. I can't imagine what would have happened if she had had no parents to support her. It certainly is time the New Zealand Government took this matter up with the American authorities. Why should these men be allowed to avoid their responsibilities? Our girls were good enough for them to marry. They should be made to maintain them" (Deserted Wives 1945).

${ }^{4}$ For a representative sample of testimonials relating to encounters between U.S. Marines and New Zealand women, see Ellis (2006).
} 
opening up of a small insular and relatively homogeneous society to foreign interventions, both collective and individual" (Wevers 1998, pp. 97-98). Among the interventions was a feature that New Zealanders could hardly have missed, namely the sheer optimism of the Americans, which signalled as nothing else could that the Great Depression had at last passed into history. No one could lament its departure, but if the onset of the Depression had come as a shock to those who enjoyed a breezy, noncommittal lifestyle, its dissolution did not mean that New Zealanders could keep pace with or wholly sanction the self-gratification of their guests. Those men who were barred from or chose not to enlist in the armed services had a different work ethic to the Americans, probably resembling something close to the quiet aloofness characteristic in John Mulgan's Man Alone (1939), which had grown out of the grey, hopeless doldrums of mass unemployment. But how different a prospect were the Andy types, standing ready as self-made men in a land of new and relatively sudden opportunity, a land that was conveniently bereft of competition from Kiwi servicemen when it came to the ladies. This is not to say that Depression-era New Zealanders had more honourable intentions than their guests. In point of fact, there was more than a little similarity between the lifestyle of the Americans and the nomadism of the depression-era swaggers. Some of the old hands in the U.S. Army (less so in the case of the Marines) would certainly have been familiar, for example, with the antics that Jack McClenaghan later wrote about in Travelling Man (1976). Common to both groups was an itinerant culture, forced or otherwise, an undying thirst for hard liquor, and a desire to 'give the ferret a run' with whomsoever should cross their paths. These aspects meant that friendships between the groups were hardly unknown, but the Americans outclassed the swaggers in several respects: they dressed well, they cared about their hygiene, and they had a steady income.

Given the absence of the Expeditionary Force and the shortcomings of a good many who remained behind, it is not surprising that the first New Zealand novel to describe the occupation retreated behind a child's view. In Norman B. Harvey's Any Old Dollars, Mister? (1964) we are presented with the spectacle of a Kiwi version of Ragged Dick running rings round the Marines, scrounging money every which ways in a series of episodes that substitutes for storyline. The putative naiveté of Americans serves as a recyclable object of ridicule from beginning to end, though anyone who had perused James Clavell's King Rat (1962) would have known that the Americans had proven themselves past masters when it came to extortion (perhaps that is partly the point). Another reason for the child's point of view comes through in the boy's Haulden Caulfield-like entry into an adult social world without an adult's knowledge of social mores. The stylistic detachment invested in this literary form permits incidents such as the confrontation between a Māori and an American to unfold through the lens of a child's wonderment, leaving it to the reader to realise their significance (pp. 40-42). Given how much is left unstated, one can infer that Harvey is treading carefully and diplomatically, conscious of how raw some injuries remain. The Americans in this novel possess no individual characters beyond their stereotypes as gum-chewing, chain-smoking, and big-spending: exactly what a child would expect them to be, and therefore harmless. 
Harvey's novel caught the last wisps of an innocent outlook that would be denied writers throughout the following decade, though the next publication, C. K. Stead's Smith's Dream (1971), is by no means wistful. In 1964, New Zealand began its first foray into Vietnam, dispatching the Royal New Zealand Engineers in a non-combat capacity (combat troops were sent the following year). Stead's work would reflect ongoing public discontentment with the war, and his vision of a right-wing coup taking hold of New Zealand with the grace and assistance of American soldiers distils a great deal of leftist indignation at the effrontery of military interventionism. The premise of the story is certainly enough to capture our attention, but at various times the scenario of guerrilla activity, transplanted from the jungles of Vietnam to the farms and bushland of New Zealand, is hard to credit and one could read Smith's Dream as a sign of cultural insecurity wherein a 'forgotten' Allied country 'recentralises' itself in the global contest between Communism and Capitalism. At any rate, the Pacific War does not enter the text apart from the excerpted denunciation that precedes this article (Stead 1971, p. 74). There, the main purpose is to deepen the reader's recollection of American 'interventions' in the Pacific, collapsing distinctions between 1942 and 1971 to suggest that the motives and behaviours of the American government and/or its military were generally akin in those two eras. While this perspective teeters on the brink of presentism, by positioning New Zealand as an early 'victim' of American imperialism Stead does much to burnish his nation's anti-hegemonic credentials. Breaking ranks with the United States really is the main point here, and the Pacific War diminishes in significance alongside that objective. But Stead's work did not signal the demise of the topic. On the contrary, his writing revealed that critiques of the 'occupation,' and of womanisers in particular, had re-entered public discourse in a more graphic, earthier form than Harvey's writing or the newspaper columns of 1945. In the following years, all that remained was to match invective with characterisation.

During the subsequent decade, grassroots and, latterly, governmental efforts to establish New Zealand as a nuclear-free nation generated considerable friction with the United States and brought the ANZUS alliance to breaking point. The time was ripe for New Zealand writers to dig up the seedier moments of the occupation, but although antinuclear civil activism drove a wedge between American global interests and New Zealand, much as the Vietnam War had done before, the 1980s were barren years when it came to recalling the occupation. Admittedly, 1983 saw the publication of Yolanda Drummond's Meeting the Americans, just one year before Prime Minister David Lange barred nuclear-powered vessels from entering New Zealand ports. In this novel, Drummond attempted to provide a retrospective meditation on wartime romances from the perspective of New Zealand women, surely a worthy topic, but one that stretched beyond the author's abilities to deliver (Drummond 1983, p. 105). Whereas Harvey's story had taken on an episodic momentum that allowed no contemplation, Drummond's was almost devoid of action and her style had a fidgety inability to get to the point. For a story grounded in wartime events, the flaw was fatal.

The 1980s also witnessed another phenomenon that gripped public attention in New Zealand, though it did not quite equal the passions of antinuclearism. The rise of 'Japan Inc.,' a metonymic shorthand for the industrial and financial muscle of that 
nation, was a regular theme in the American press, which noted wryly that Japanese companies appeared to be getting stronger just as the Detroit auto industry was weakening. Some commentators quipped that 'cococolonisation' had been replaced by 'sake imperialism' (Robins and Morley 1991, p. 32). For their part, New Zealanders had less to fear from the flexing of Japan's corporate muscle because their domestic industries of dairy, agricultural, and forestry products were neither outcompeted nor acquired by Japan's hi-tech conglomerates. But neither could New Zealanders feel comfortable with the rising number of Japanese tourists that arrived at their shores. Right around the same time that David Lange was giving his famous Oxford Union Address, in which he accused the United States of bullyboy tactics in international relations, Keri Hulme published her short story, "Kaibutsu-San" (1985), in which she painted a sinister portrait of an acquisitive Japanese tourist with a voracious appetite. The congruence of these two moments puts paid to any idea that New Zealand's nuclear-free policies might have translated into newfound chumminess with the Japanese. New Zealanders were entirely capable of thumbing their antinuclear noses at the United States, but when it came to Japan their attitudes were largely in accord with American anxieties. This situation meant that, as long as the discourse of 'Japan panic' was in circulation, literary reappraisals of the occupation ran the risk of dealing too harshly with those Americans who had saved New Zealand from a threat that now appeared resurrected in a different form. Only after Japan's economic 'bubble' had burst would a work emerge that took an empathetic view of Japan's warrior spirit of bushido alongside a discerning appraisal of how American troops behaved in New Zealand. That is what we get in Pat Booth's journalistic novel, Sons of the Sword (1993), thus far the most ambitious, and certainly the most thoroughly researched literary work to take the occupation as its topic. 5

At first glance, however, Booth's novel may feel like a throwback to Any Old Dollars, Mister? because of the child's perspective that predominates-or rather, a man's memories of his childhood-but whereas Harvey's larrikin protagonist was too excitable to be bothered by American behaviour, Paul is a character who is deeply troubled by what he sees, though it takes him a lifetime to work out the implications of his younger self's boyhood encounters. As the story unfolds, we discern his preoccupation with the arrival of a U.S. Marine into his family home, a common occurrence during the war, particularly in and around Wellington. The guest has with him a splendid Japanese sword that, displayed in front of the family, provokes a telling response from the onlookers:

Paul's mother stood up quickly, emptying a flurry of cat and knitting from her lap, and eased the old bowl their grandmother had left them away from the table top. It would give more room, she said. They all knew she meant that it was too precious to lose and that she felt it was at risk anywhere now but on the sideboard.

\footnotetext{
${ }^{5}$ Booth received a grant from the Japan Foundation to assist in the research of the novel, which he used to fund research activities at the Tokyo National Museum, the Yasukuni Shrine, and the Hiroshima and Nagasaki Peace Memorial Museums, among others.
} 
Then quiet again, before the slight rasp of the blade clearing the lip of the scabbard. Paul's mother gasped and his sister made a noise which he thought was simply a stupid giggle. Later, he realised it was a mark of a number of emotions even she did not recognise.

Fifty years later he tried to redraw the precise picture in his mind, recapture the memory in its full detail. Was it the chilling flash of the cutting edge which so shook his mother, or the curve of it, or perhaps the palm-greased binding on the hilt (pp. 13-14)?

Or perhaps something else. Booth is aware of how swords function heraldically as a representation of national conquest, and also of the Freudian overtones of sexual prowess bound up in their phallic symbolism. These 'interpenetrative' connotations are equally implied in the Marine's 'exposure' of a weapon that, were it not for him, might otherwise have reached New Zealand under very different circumstances. Having 'castrated' the enemy before he could do so, it is the Marine's pleasure to assume the role of protector and inseminate his defenceless hosts, culturally or otherwise. Thus we see how easily the role of a protector can segue into the right of conquest, and how the psychology of the protected colludes, however unknowingly, in the process. New Zealand writing had shown some awareness of this dark truth before, notably in A Soldier's Tale, but Booth was alone in daring to suggest that the rule held true within his own country as well as in conquered territories overseas. Forty years previously, American writers had had some inkling of what their servicemen got up to and, as we have seen, they did not shy from seduction as a theme (Uris, in particular, had a wicked gift for knowing what his characters wanted, even if he never allowed them to follow through). But their depictions were in a linear, realist mode that appeared almost sociological at times, locking characters within a hunter-prey binary. The complex patterning of wartime gender relations was concealed behind this framework, and it also tended to focus attention upon relationships between an American male and a New Zealand female to the exclusion of New Zealand men. In Booth's writing, by contrast, characters are not always aware of their effect upon others, or of what is being done to them, and we see that, quite apart from being mere onlookers, Kiwi males are deeply implicated in the internationalised landscape of gender relations. When Paul's father brandishes a souvenir enemy carbine and goes on an anti-Japanese rant, for example, the reader quickly perceives that he is vocalising the outrage of his own gelding, brought on by the occupation and deflected against the enemy in ways more potent than any internalised propaganda (p. 83). What is at stake here is not only the sexual privilege of paterfamilias, but also his nagging suspicion that male sexuality is in some way contingent upon a demonstrable commitment to national defence. The arrival of the U.S. Marines, and their subsequent success in romancing local women, would not have come about, that is, had New Zealand males been on hand to man the beachheads against invasion. But they were not on hand. For the most part they were in Europe and North Africa, as they had been during the Great War, and the sense of seconded, even redundant military purpose in the Pacific was especially injurious to a 'masculine' society used to receiving praise for fighting overseas. One could hardly blame the Americans for lending a hand, but it was entirely possible, and 
natural, to blame the Japanese for forcing New Zealanders to accept the American hand. Paul's father does not articulate the intricacies of this psychology, but his behaviour bears out the premise and we thereby come face-to-face with one of the most striking implications of Booth's novel: the strength of anti-Japanese prejudices within New Zealand society and the way in which sexual competition with American servicemen provided fertile soil within which those prejudices could take deeper root.

Among the depictions of wartime romance that have appeared in New Zealand fiction thus far, Booth's novel is undoubtedly the most multifaceted. Not only does the Marine carry on a romance with Paul's sister, leading to illegitimate pregnancy, temporary exile of the sister from the community, and compulsive adoption of the bastard child, he also manages to seduce Paul's mother as well. Most of Paul's tortured reminiscences derive from the awkwardness that enters family relations once these events interpose themselves between husband and wife, mother and daughter, sister and brother, and so on. As for the Marine, the nature of his dangerous profession and the fact of his friendly disposition make it impossible to wish him ill, and yet his actions within the family make it equally impossible to wish for his return. That he is exploitative beyond the level of the average philanderer is unquestionable, but at no stage does he appear utterly villainous. He remains but one among many who would have done likewise, given an opportune moment, or so we might assume. Then again, if we choose to dismiss the Marine as one of a kind, we need to be on our guard against overstating the case for a homogeneous code of social conduct in the United States armed forces of the period. Up until today, New Zealand fiction writing has largely dispensed with the moral diversity and personal idiosyncrasies of American servicemen as a constituent literary feature, preferring instead to deepen and complicate the characterisation of New Zealand civilians. Perhaps this tradeoff is inevitable to a society and culture increasingly willing to recognise sexual victimisation alongside the love matches of the war years, but portrayals need not and ought not to remain tipped any one way. Well drawn characterisations of American servicemen do not have to come at the expense of civilian New Zealanders and we may therefore say that, if worthwhile literary fictions by and about women remain an obvious, perhaps the most obvious absence in the literary record thus far, another frontier would be a New Zealand work that fashions characterisations of Americans with the confidence, if not the style, of Michener and Uris.

New Zealand writers have not yet reached either of these goals, though a recent attempt at the latter was made by Nicholas Edlin in his novel, The Widow's Daughter (2010), which features a United States Marine Surgeon as protagonist. Edlin's fascination with the society of American servicemen is evident throughout, but at various times it is hard to tell whether he has really taken their world as his canvas or grafted it onto the older lineage of the espionage thriller (the hapless Marine falls in love with an undercover Nazi). No matter the original intent, Edlin's literary talent lies in neither of these areas, but rather in a staple of New Zealand fiction, which sees the writer drawing back in horror at the visage of a settler society founded on meat processing. To some extent, the Pacific War diverted people's attention from this day-to-day industry, but Edlin suggests that butchery retained its position at the centre 
of New Zealand domestic affairs, courtesy of the American military hospital operating outside Auckland at the time. In a grotesque twist, New Zealand's main business now involved throwing 'meat production' into reverse by stitching up the mauled tissues of human 'matériel' arriving from Guadalcanal, which, as Edlin rightly surmises, was a first for the country. At the time of the Great War, much emergency medical treatment had taken place on the Western Front, at Gallipoli, or in England and in Egypt. But during the Pacific War, that role fell to Auckland and Edlin is at his best when he unflinchingly describes the stitching, cutting, suturing, and amputating of American casualties. The world of the operating theatre exercises a strong hold over the text, partly because of the 'visceral' nature of imagery, and partly because Edlin is aware that he is writing of a topic about which most New Zealanders know little. But as the steady hands of the surgeon check the pace of the narrative, so the harsh fists of the Auckland streets remind us of the 'localised' altercations that, while stopping short of murder, evince an animalistic fury. Unlike Michener's account, the brawls that take place in The Widow's Daughter are not traceable to anything as neatly categorised as 'race relations' or 'gender relations,' but emerge from a primal reaction to, or rehearsal of, the death-dealing campaigns to the north. Between the kicks and the punches, the circumstantial provocations that give rise to the violence, whatever they may be, diminish in significance and, in their stead, a series of troubling questions come to the fore: Do the American personnel vent their spleen on the local populace as a stand-in for an enemy they have not yet encountered? Do 'non-combatant' civilians likewise unburden themselves, 'manufacturing' social confrontations with their guests to appease their consciences of the blood sacrifice that the United States servicemen undertake in their name? In an age of industrial warfare, was this nothing more than Saturnalia?

It is tempting if not irresistible to hazard an answer or two to these questions, but whatever comes to mind, one thing is apparent, namely that meditating on the ramifications takes us far beyond the confines of Auckland, or New Zealand, or, indeed, anywhere else. The scale of comparative potential contained therein is beyond the scope of this article to address, but I believe that a cursory consideration of other occasions, other countries, and other wars would bear out the enduring value of an investigation. In Edlin's novel, we get a fleeting glimpse of how the violent intermingling of national cultures transcends their spatial and temporal context, acquiring a timelessness as evocative as that of the 'fallen woman' who cynically rests in the arms of an invading army. Unfortunately, though, Edlin is better at constructing provocative scenarios than he is at explaining their significance and he chooses to end his novel in a Californian sunset rather thanin my opinion, a better alternative-the sinister symbolism of Perfectus, an incinerator unit that repeatedly figures in the Auckland landscape. Mutely significant, Perfectus is, of course, a throwback to the 'wasteland' imagery of Great War literature, wherein everyday habits become overshadowed by a recurrent image, or other refrain, that forever calls to mind the 'meat grinder' of mass death on the battlefield. No character ever visits Perfectus, much less enters it, but Perfectus, by its mere presence, penetrates into everyone's individual consciousness until the steady build up of pressure seeks its inevitable release. 
In 1940, New Zealand celebrated the Centennial of British government. Little over a year later, the country was a giant billet (or bidet) for American troops. The ironies of this turnaround must have contained a strain of bitterness for many, yet New Zealand was spared the shock of receiving foreign servicemen in such numbers as to overwhelm its own population. ${ }^{6}$ At no time were Americans ever in the majority, and so what took place cannot be measured in terms of population displacement at the level of whole islands, cities, or villages, but rather at the disaggregated level of individual households whose families, intact at the outbreak of war in 1939, endured the departure of their male relatives in the first instance, and then went on to witness the arrival of foreign servicemen as a consequence. Strictly speaking, this was not the first time in which American and New Zealand armed forces had worked together. Although the New Zealand armed forces were fully integrated into the Imperial Defence System, its servicemen had found themselves supported by the American military at various times, as during the Great War; or working entirely without them, as in the Boer War. Still, in either case, New Zealand's experience of acting with the United States provided no foreknowledge of or preparation for being seconded to the United States. Militarily speaking, of course, the arrangement must be judged a resounding success, but campaign history has not been our concern in this article. Rather, the social complexities, as measured and reflected in literary fictions, have served to indicate how Americans and New Zealanders reacted to one another, not so much at the time of the encounters themselves as when creative writers had the leisure to turn over the events retrospectively. We have seen how the resourceful fiction writers James A. Michener and Leon Uris proceeded to stake out the principal issues of racial tension, in the first instance, and gender relations more especially, with artistic sensitivity. Uris' novel, in particular, deserves recognition as the first book-length attention to New Zealand by an American literary writer since Mark Twain visited in 1895 and wrote More Tramps Abroad (1897). However, Michener and Uris both underestimated the degree to which these respective phenomena had impacted upon New Zealanders. Not only that, but we may say, also, that New Zealand writers such as Norman B. Harvey likewise tiptoed around scenes involving Māori and American conflict, or womanising as a pastime of American servicemen. Only in the last couple of decades, with the arrival of publications that give serious consideration to the issues at hand, have we witnessed an increased willingness in New Zealand fiction writing to be upfront about the less edifying moments of the American occupation: the deep scars endured by women, and sometimes whole families, at the hands of uniformed philanderers; or the unthinkable spectacle of civil society degenerating into mob violence, not as a one-off but as a regular feature of urban life. That writers should focus upon these instances in particular does not imply the telltale power of anti-Americanism, either as a theme within literature or a discursive trend in New Zealand society at large. On the contrary, when literary writers move to position their topics as 'timeless' or universal, as I have suggested

\footnotetext{
6 The notion of American troops in World War II 'overwhelming' a host society by their sheer numbers may appear so outlandish as to be barely worth mentioning, and yet this was in fact the case in Trinidad, Greenland, and those Pacific Islands with a population many times smaller than New Zealand's (Coates and Morrison 1991, p. 213).
} 
may be detectable, at times, in the most recent writings, it suggests the opposite, in intention if not in result. A writer who transcends national grievances by situating them within the story of humanity, that is, cannot remain entirely bound by the ideology of nationalism and, by extension, is unlikely to feel pulled toward antiAmericanism.

Acknowledgment The author wishes to thank the National Research Foundation (South Africa) for postdoctoral funding that aided in the completion of this article.

\section{References}

Bioletti, H. (1989). The Yanks are coming: The American invasion of New Zealand 1942-1944. Auckland: Century Hutchinson.

Booth, P. (1993). Sons of the sword: A novel of the Pacific War. Auckland: Alister Taylor.

Burdick, E., \& Lederer, W. (1958). The ugly American. New York: Norton.

Clavell, J. (1962). King rat. New York: Little, Brown and Company.

Coates, K., \& Morrison, W. R. (1991). The American rampant: Reflections on the impact of United States troops in Allied Countries during World War II. Journal of World History, 2(2), 201-221.

Deserted Wives. (1945, Oct 17). N.Z. Truth, p. 13.

Drummond, Y. (1983). Meeting the Americans. Auckland: Hodder and Stoughton.

Edlin, N. (2010). The widow's daughter. North Shore: Penguin.

Ellis, J. (2006). A string of pearls: Stories from US marines \& New Zealand women remembering WWII. Wellington: First Edition.

Harvey, N. B. (1964). Any old dollars, mister?. Auckland: Paul's Book Arcade.

Himes, C. (1945). If he hollers let him go. New York: Doubleday Doran.

Hitchens, C. (2010). Hitch-22: A memoir. Crows Nest, NSW: Allen \& Unwin.

Hulme, K. (1985). Kaibutsu-San. Landfall, 39(4), 458-464.

Joseph, M. K. (1976). A soldier's tale. Auckland: Collins.

Lighter, J. (2011). Battle cry revisited: "Don't worry, mom, everything is going to be all right". War, Literature, and the Arts: An International Journal of the Humanities, 23. Retrieved from http://wlajournal.com/23_1/images/lighter.pdf. Accessed 1 March 2012.

Lissington, M. P. (1972). New Zealand and the United States-1840-1944. Wellington: A. R. Shearer. McClenaghan, J. (1976). Travelling man. Auckland: Collins.

Michener, J. A. (Ed.). (1951). Until they sail. In Return to paradise (pp. 212-263). Harmondsworth: Penguin.

Mulgan, J. (1939). Man alone. London: Selwyn and Blount.

Orders, P. G. A. (2003). Britain, Australia, New Zealand and the challenge of the United States, 1934-1946: A study in international history. Basingstoke: Palgrave Macmillan.

Parr, A. (2010). Home: Civilian New Zealanders remember the Second World War. Auckland: Penguin. Phillips, J., \& Ellis, E. (1992). Brief encounter: American forces and the New Zealand people 1942-1945: An illustrated essay. Wellington: Historical Branch, Department of Internal Affairs.

Robins, K., \& Morley, D. (1991). Japan panic. Marxism Today, pp. 32-35.

Stead, C. K. (1971). Smith's dream. Auckland: Longman Paul.

Twain, M. (1897). More tramps abroad. London: Chatto \& Windus.

United States troops in New Zealand. (2000). In I. McGibbon (Ed.), The Oxford companion to New Zealand military history (pp. 550-552). Auckland: Oxford University Press.

Uris, L. (2005 [1953]). Battle cry. New York: Avon Books.

Wevers, L. (1998). Speaking for ourselves in 1945. Journal of New Zealand Literature, 16, 97-111. 